\title{
SLIDING-WEAR BEHAVIOR OF ALUMINUM-MATRIX COMPOSITES REINFORCED WITH GRAPHENE AND SiC NANOPARTICLES
}

\author{
DRSNA OBRABA KOMPOZITOV NA OSNOVI ALUMINIJA, \\ OJAČANIH Z NANODELCI GRAFENA IN SiC
}

\author{
Kaifeng Zheng, Xiaoming Du*, Haotian Qi, Tong Zhao, Fengguo Liu, Bo Sun \\ School of Materials Science and Engineering, Shenyang Ligong University, Shenyang 86110159, China \\ Prejem rokopisa - received: 2019-05-16; sprejem za objavo - accepted for publication: 2019-09-18
}

doi:10.17222/mit.2019.104

\begin{abstract}
The microstructure, hardness and tribological properties of hot-pressed Al 7075 matrix composites containing the same SiC nanoparticles and different amounts of graphene were investigated. The results show that the Al-SiC-graphene composites exhibit higher hardness and wear resistance compared with Al-SiC composite and Al 7075 alloy.The friction coefficients decrease significantly with the increase of graphene content in the composites, whereas the limited impact on reducing friction is found on $\mathrm{SiC}$ nanoparticles. The dominant wear mechanism of Al-SiC-graphene composites transfers from abrasive wear to delamination wear with the increase of graphene content in the composites. It is believed that the hardness and wear-resistance improvements of the Al-SiC-graphene composites are attributed to the unique strengthening effect as well as the good lubricating efficiency of graphene, which demonstrates that graphene is an ideal filler for aluminum-matrix composites, acting as not only a favorable reinforcement but also an impactful lubricant.
\end{abstract}

Keywords: graphene, SiC nanoparticle, aluminum matrix composite, wear mechanism

Avtorji v članku opisujejo analizo mikrostrukture, meritve trdote in določitev triboloških lastnosti vroče stisnjenih kompozitov z matrico iz zlitine Al 7075, ki so vsebovali enako količino nanodelcev SiC in različne vsebnosti grafena. Rezultati raziskav so pokazali, da imajo Al-SiC-grafen kompoziti večjo trdoto in odpornost proti obrabi v primerjavi z Al-SiC kompozitom in zlitino Al 7075. Koeficienti trenja se znatno zmanjšujejo $\mathrm{z}$ naraščajočo vsebnostjo grafena v kompozitih, medtem ko so avtorji ugotovili, da $\mathrm{SiC}$ nanodelci vplivajo na oz. omejujejo zniževanje koeficienta trenja. Prevladujoč mehanizem obrabe kompozitoy Al-SiC-grafenov prehaja $\mathrm{z}$ abrazije na delaminacijo (luščenje ploščic s površine) $\mathrm{z}$ naraščajočo vsebnostjo grafena $\mathrm{v}$ kompozitih. Avtorji članka pripisujejo zvišanje trdote in povečanje odpornosti proti obrabi Al-SiC-grafen kompozitov edinstvenemu utrjevalnemu učinku in dobri mazalni učinkovitosti grafena. To potrjuje predpostavko, da je grafen idealno polnilo za kompozite s kovinsko matrico iz Al zlitin, ki ne deluje samo kot dobra ojačitev, temveč tudi kot udarno mazivo.

Ključne besede: grafen, SiC nanodelci, kompozit z matrico iz Al, mehanizem obrabe

\section{INTRODUCTION}

Aluminum-matrix composites (AMCs) have attracted extensive attention in recent years because of their excellent mechanical properties, high strength, excellent wear resistance and lightweight properties. ${ }^{1,2}$ They have a wide range of applications in aerospace, military, automotive and other fields. Among the many reinforcing phases, such as graphite, ${ }^{3}$ carbon nanotube, ${ }^{4} \mathrm{SiC}_{\mathrm{P}}{ }^{5} \mathrm{~B}_{4} \mathrm{C},{ }^{6}$ silicon carbide and graphene are considered to be excellent reinforcements of AMCs because of their good physical and chemical properties. ${ }^{7}$

At present, silicon-carbide-reinforced metal-matrix composites have been reported in many publications, ${ }^{8,9}$ so that their wear resistance has been improved well. It is pointed out that increasing ceramic reinforcement phase is one of the main ways to improve the wear resistance of alloys. ${ }^{10}$ However, it has also been reported that soft-particle lubrication and hard-particle reinforcement are the inevitable trends to improve friction properties. ${ }^{11}$

*Corresponding author's e-mail:

du511@163.com (Xiaoming Du)
Before this, the lubrication effect of graphene on the wear behavior has been reported in many papers. ${ }^{12,13} \mathrm{M}$. R. Akbarpour et al. ${ }^{14}$ studied the friction properties and wear behavior of $\mathrm{SiC}$ and $\mathrm{CNT}$ hybrid reinforced copper-matrix composites, and pointed out that a uniform lubrication layer was formed on the worn surface. $\mathrm{SiC}$ and graphite hybrid reinforced A356 composites were prepared. ${ }^{15}$ The wear properties and friction properties of A356 composites were also studied. The results show that the friction coefficient of hybrid composites is not decreased by the addition of graphite, but the wear rate of hybrid composites is reduced by the presence of $\mathrm{SiC}$ particles. Although some valuable research has been concentrated on the effect of pure $\mathrm{SiC}$ and graphenereinforced aluminum composites, there are rare studies on the binary SiC-graphene-reinforced hybrid composites.

In this study, graphene and $\mathrm{SiC}$ nanoparticles hybrid reinforced Al7075 composites were prepared by the hot-pressing method. This study aims to investigate and compare the effect of pure $\mathrm{SiC}$ and synergistic binary SiC-graphene addition on the density, hardness, tribo- 
logical properties, and microstructure of aluminum hybrid composites.

\section{EXPERIMENTAL PART}

\subsection{Materials}

A17075 (Al-Zn-Mg-Cu alloy) powder (10 $\mu \mathrm{m}$, supplied from Beijing Hongyu Materials Company) was used as the matrix material. Graphene and SiC nanoparticles $(800 \mathrm{~nm}$, supplied from Shanghai Yunfu Nanotechnology Co., Ltd.) were used as reinforcement phases. The graphene is the commercial agent from Nanjing XFNANO Materials Tech Co., Ltd. All of the above materials were used without further purification.

Three samples were prepared by hot pressing in a vacuum at $610^{\circ} \mathrm{C}$ for $1.5 \mathrm{~h}$ under a pressure of $50 \mathrm{MPa}$, in which these samples have the same $\mathrm{SiC}$ content of $0.25 w / \%$ and different graphene content, which were $0 w / \%$ (Al-SiC), $0.25 w / \%$ (Al-SiC-Gr 1 ) and $0.5 w / \%$ (Al-SiC-Gr2), respectively. The preparation methods of the composites are reported in our previous work. ${ }^{16}$

All the composite samples were subjected to solutionizing at a temperature of $470{ }^{\circ} \mathrm{C}$ for $2 \mathrm{~h}$ followed by quenching using cold water. The quenched samples are then subjected to artificial aging for $16 \mathrm{~h}$ at a temperature of $140{ }^{\circ} \mathrm{C}$.

\subsection{Characterization and dry sliding wear test}

The X-ray diffraction patterns of the samples were recorded on Rigaku Ultima IV X-ray diffractometer using $\mathrm{Cu}-K_{\alpha}(\lambda=0.15406 \mathrm{~nm})$ radiation. Slow scans of the selected diffraction peaks were carried out in the step mode. The step size is $0.02^{\circ}$. The diffraction angle $(2 \theta)$ was maintained between $20^{\circ}$ and $100^{\circ}$. The average grain size was calculated by Williamson-Hall method. ${ }^{17}$ The density of the composite materials was measured by Archimedes' method. The Vickers hardness of the sample was measured by a Vickers hardness instrument (HVS-50, Shanghai, China). The load force was set to $9.8 \mathrm{~N}$ and the dwell time was $10 \mathrm{~s}$. The average hardness of the material is measured at least ten times in different areas of each sample.

A reciprocating friction and wear tester (MDW-02, Jinan,China) was used for the dry-sliding wear tests. All the samples were polished before wear testing to ensure that the surface of the sample has the same roughness. The dry wear tests were carried out at room temperature using a load of $10 \mathrm{~N}$. The average sliding speed in the wear tests is $0.02 \mathrm{~m} / \mathrm{s}$ and the total sliding distance is 24 $\mathrm{m}$. Balls with a diameter $6.35 \mathrm{~mm}$ and made of GCr15 bearing steel (HRC63 \pm 3 ) were used for the wear tests. The average friction coefficient is calculated under steady-state conditions in which the wear test reaches the steady state for more than $90 \mathrm{~s}$. The worn surface and balls surface were analyzed using a scanning electron microscope (TESCAN) equipped with EDS. The wear volume of the samples was analyzed based on the depth and width of the wear trajectory for pure and composite samples using a laser scanning confocal microscopy (LSCM) (LEXT OLS4100, Japan). The morphology of the debris produced by different samples in wear test was analyzed by scanning electron microscope (HITACHIS3400 N, Japan). The structures of the graphene during sintering and sliding were investigated by Raman spectroscopy using a Jobin-Yvon microspectrometer (LabRam HR, Jobin-Yvon Co. Ltd., France). The spectra were collected under ambient condition using the 514.5-nm line of an argon-ion laser.

\section{RESULTS AND DISCUSSION}

\subsection{Microstructure}

The X-ray diffraction patterns of three composite samples with different graphene content and the same $\mathrm{SiC}$ content are shown in Figure 1. The diffraction peaks of $\alpha-\mathrm{Al}, \mathrm{SiC}, \mathrm{MgZn}_{2}$ and graphene were retrieved. As can be seen in Figure 1, all the samples have major $\alpha-\mathrm{Al}$ peaks at $38.4^{\circ}(111), 44.7^{\circ}(200), 65.1^{\circ}(220), 78.2^{\circ}$ (311), $82.4^{\circ}(311)$ and $99.1^{\circ}(400)$. In addition to the diffraction peaks of $\alpha$-Al matrix, some very weak diffraction peaks were also found. The intensity of these peaks is relatively weak. It is possibly due to the small amount of graphene and $\mathrm{SiC}$ nanoparticles in the composites. The weak diffraction peaks located at $26.5^{\circ}$ (002) for Al-SiC-Gr2 and Al-SiC-Gr1 samples are of character peak in carbon X-ray diffraction pattern, which indicates that graphene has been integrated into the matrix materials. The result is consistent with that reported in the literature. ${ }^{18}$ The intensity of the diffraction peak for graphene decreases with the decrease of the content of graphene, such as Al-SiC-Gr1 sample. The weak diffraction peaks located at $35.8^{\circ}$ (103) and $60.1^{\circ}(110)$ in the three composites are of character peak in $\mathrm{SiC}$ with a trigonal crystal structure $\mathrm{X}$-ray diffraction

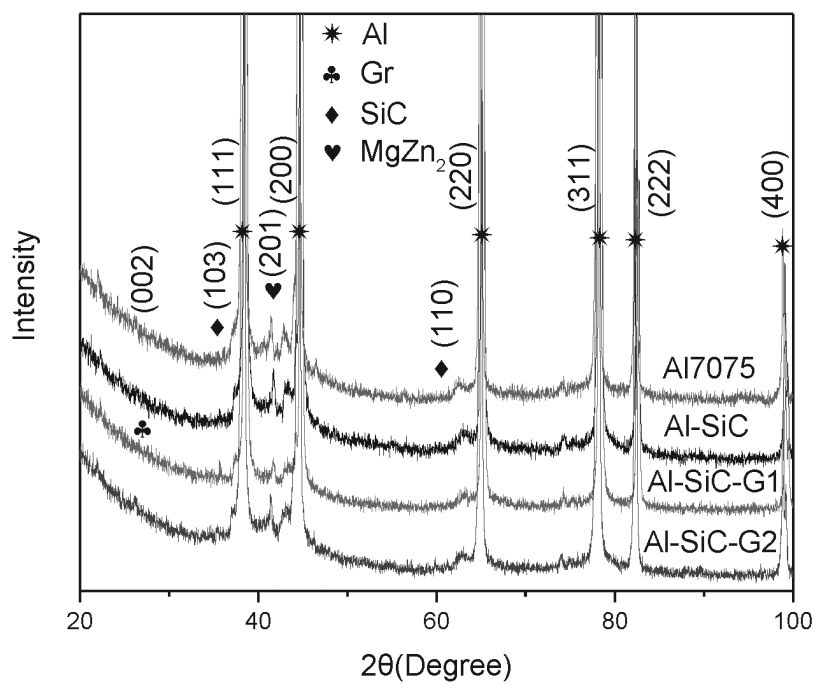

Figure 1: XRD patterns of Al-SiC, Al-SiC-Gr1 and Al-SiC-Gr2 
pattern. Moreover, aluminum carbide $\left(\mathrm{Al}_{4} \mathrm{C}_{3}\right)$ peaks were not found in this analysis, indicating the better potential of graphene in strengthening Al-based composites.

Table 1 summarizes the relative density and mean crystal grain size of the three composites. The relative densities of all the composite samples are more than $99 \%$, which shows that the prepared composites are dense, and the porosity of the composite is low. The relative density of the composites shows an decrease with increasing graphene contents. This may be attributed to the low density of graphene.

Table 1: The samples and measured properties

\begin{tabular}{|c|c|c|}
\hline Sample & Relative density (\%) & Grain size (nm) \\
\hline Al7075 & - & $3225.00 \pm 3.67$ \\
\hline Al-SiC & 99.4 & $1119.80 \pm 0.45$ \\
\hline Al-SiC-Gr1 & 99.4 & $790.20 \pm 3.63$ \\
\hline Al-SiC-Gr2 & 99.2 & $427.20 \pm 9.39$ \\
\hline
\end{tabular}

From the mean grain size of the three composites obtained from XRD in Table 1, it can be seen that the content of graphene has a significant effect on the grain size of aluminum matrix composites. A fine dispersion of the $\mathrm{SiC}$ nanoparticles and graphene in the matrix may prevent the grain growth of the matrix alloy during the hot-pressing process. Grain size decreases with increasing the graphene content. With an increase in the content of the graphene, the area of interface boundaries between the graphene and Al matrix increases and the dislocations are piled up at the interface boundaries similar to the grain boundaries. Apart from the dispersion strengthening effect, the addition of the graphene refines the grain size and introduces a high dislocation density in the matrix.

\subsection{Hardness}

Results from the Vickers hardness test of Al-SiC, Al-SiC-Gr1 and Al-SiC-Gr2 are shown in Figure 2. In previous work, the Vickers hardness of A17075 alloy prepared by the same method and parameters was 92.0 \pm 4.6 HV. ${ }^{16}$ It can be seen from Figure 2 that the

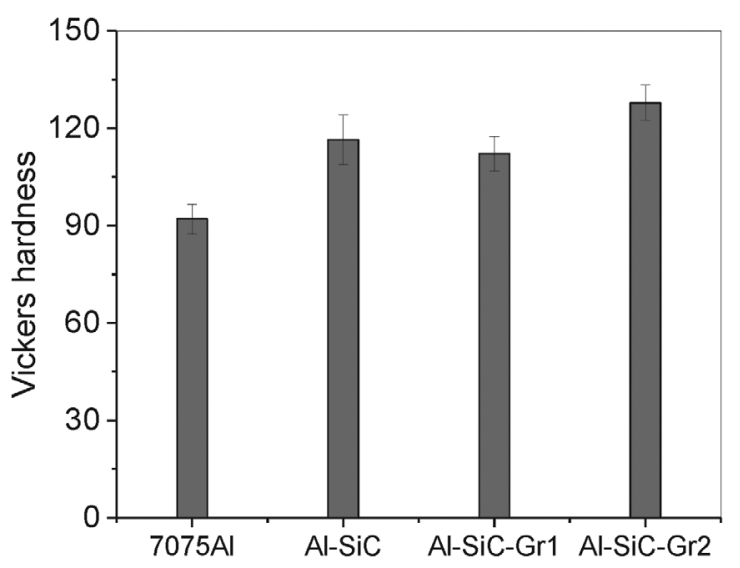

Figure 2: Hardness of of Al-SiC, Al-SiC-Gr1 and Al-SiC-Gr2 hardness of the three composites samples is significantly higher than that of the Al7075 alloy, which represents an increase of $26.6 \%, 21.9 \%$ and $38.9 \%$ for $\mathrm{Al}-\mathrm{SiC}$, $\mathrm{Al}-\mathrm{SiC}-\mathrm{Gr} 1$ and Al-SiC-Gr2, respectively. The increase of the hardness results from dispersion strengthening of $\mathrm{SiC}$ nanoparticles and graphene, refining grain strengthening of the aluminum matrix and thermal mismatches between $\alpha$-Al and $\mathrm{SiC}$, graphene. The mismatch strain due to the difference of the coefficient of thermal expansions between the $\mathrm{SiC}$ nanoparticles, graphene and Al matrix develop high-density dislocations, which strengthens the matrix. SiC nanoparticles, graphene obstruct the movement of high density dislocations, resulting in an improvement of the hardness.

\subsection{Tribological properties}

The variation in the measured average coefficient of friction $\left(\mathrm{COF}_{\text {average }}\right)$ with the weight percent of graphene in the hybrid-reinforced composites is shown in Table 2. The results show that within the set of test conditions used, the average coefficient of friction in the Al7075 alloy is larger than that of the composites. And the coefficient of friction in composites significantly decreased with an increase of the graphene content in the composites. The coefficient of friction decreased by about $22 \%$ and $43 \%$ with the reinforcement of $0.25 w / \%$ and $0.5 w / \%$ graphene, respectively. This shows that graphene plays a role in the lubrication in the wear test of the composites. The existence of graphene makes the matrix form a uniform and continuous selflubricating layer on the worn surface during the wear test. The extremely effective lubrication of graphene was previously reported..$^{12,13}$

Table 2: The average coefficient of friction and depth, width of the wear track of the composite samples

\begin{tabular}{|c|c|c|c|c|}
\hline \multirow{2}{*}{ Sample } & \multicolumn{2}{|c|}{$\begin{array}{c}\text { Average coefficient of } \\
\text { friction }\end{array}$} & $\begin{array}{c}\text { Depth } \\
(\mu \mathrm{m})\end{array}$ & $\begin{array}{c}\text { Width } \\
(\mu \mathrm{m})\end{array}$ \\
\cline { 2 - 3 } & Exp. & Cal. & 65 & 270 \\
$\mathrm{Al} 7075$ & 0.39 & - & 65 & 225 \\
$\mathrm{Al}-\mathrm{SiC}$ & 0.37 & 0.33 & 54 & 144 \\
$\mathrm{Al}-\mathrm{SiC}-\mathrm{Gr} 1$ & 0.29 & 0.32 & 33 & 93 \\
$\mathrm{Al}-\mathrm{SiC}-G \mathrm{C} 2$ & 0.21 & 0.31 & 21 & 93 \\
\hline
\end{tabular}

In the studies of P. V. Trinhet al. ${ }^{19}$ and M. R. Akbarpour et al., ${ }^{14}$ a theoretical calculation method for the coefficient of friction based on hybrid criterion is proposed, and it is pointed out that the content of the reinforcing phase on the friction surface is independent of the load force applied in the wear test. At the same time, the calculation formulas of theoretical coefficient of friction are also proposed. The formulas for calculating $\mathrm{Al}-\mathrm{SiC}$ and $\mathrm{Al}-\mathrm{SiC}-\mathrm{Gr}$ composites are as follows in Equations (1) and (2):

$$
\mu_{\mathrm{Al}-\mathrm{SiC}}=\frac{\mu_{\mathrm{Al}}\left(A-A_{\mathrm{SiC}}\right) E_{\mathrm{Al}}+\mu_{\mathrm{SiC}} A_{\mathrm{SiC}} E_{\mathrm{SiC}}}{A_{\mathrm{SiC}} E_{\mathrm{SiC}}+\left(A-A_{\mathrm{SiC}}\right) E_{\mathrm{Al}}}
$$


$\mu_{\mathrm{Al}-\mathrm{SiC}-\mathrm{Gr}}=\frac{\mu_{\mathrm{Al}}\left(A-\left(A_{\mathrm{Gr}}+A_{\mathrm{SiC}}\right)\right) E_{\mathrm{Al}}+\mu_{\mathrm{Gr}} A_{\mathrm{Gr}} E_{\mathrm{Gr}}+\mu_{\mathrm{SiC}} A_{\mathrm{SiC}} E_{\mathrm{SiC}}}{A_{\mathrm{Gr}} E_{\mathrm{Gr}}+A_{\mathrm{SiC}} E_{\mathrm{SiC}}+\left(A-\left(A_{\mathrm{Gr}}+A_{\mathrm{SiC}}\right)\right) E_{\mathrm{Al}}}$

where $\mu_{\mathrm{Al}-\mathrm{SiC}}, \mu_{\mathrm{Al}-\mathrm{SiC}-\mathrm{Gr}}, \mu_{\mathrm{Al}}, \mu_{\mathrm{Gr}}$ and $\mu_{\mathrm{SiC}}$ are the coefficients of friction of Al-SiC composites, Al-SiC-Gr composites, A17075, graphene and SiC, respectively. A, $A_{\mathrm{Gr}}$ and $A_{\mathrm{SiC}}$ represent the mass fraction of $\mathrm{Al7075}$, graphene and $\mathrm{SiC}$, respectively. $E_{\mathrm{Al}}, E_{\mathrm{Gr}}$ and $E_{\mathrm{SiC}}$ represent the elastic modulus of A17075, graphene and $\mathrm{SiC}$, respectively. The data required to calculate the friction coefficient are shown in Table 3 .

Table 3: The data for calculating theoretical friction coefficients

\begin{tabular}{|c|c|c|c|c|c|c|}
\hline Symbol & $\begin{array}{c}E_{\mathrm{Al}} \\
(\mathrm{GPa})\end{array}$ & $\begin{array}{c}E_{\mathrm{Gr}} \\
(\mathrm{GPa})\end{array}$ & $\begin{array}{c}E_{\mathrm{SiC}} \\
(\mathrm{GPa})\end{array}$ & $\mu_{\text {Graphite }}$ & $\mu_{\mathrm{SiC}}$ & $\mu_{\mathrm{Al}, \text { average }}$ \\
\hline Value & 70 & $1000^{20}$ & $420^{14}$ & 0.1 & $0.7^{14}$ & 0.39 \\
\hline
\end{tabular}

Because the coefficient of friction of graphene has not been reported at present, it is replaced by the friction coefficient of graphite. However, there are also many reports that the coefficient of friction of graphene will be much lower than that of graphite. ${ }^{21-22}$ The theoretical and experimental values of the coefficient of friction of the three composite samples are shown in Table 2 . It can be seen that there is a certain difference between the theoretical values and the experimental values. The difference increases with the increase of graphene content. There are possibly two reasons for this phenomenon. Firstly, the dispersion of the reinforcing phase in the A17075 matrix alloy is assumed to be completely dispersed and uniform in the calculation of the theo- retical coefficient of friction. However, the dispersion of the reinforcing phase in the Al7075 matrix alloy is not completely uniform. Moreover, the coefficient of friction of graphene is replaced by the coefficient of friction of graphite that should be greater than that of graphene. This results in the theoretical value of friction coefficient of composites being higher than the experimental value. With the increase of graphene content, this deviation becomes more serious.

The depth and width of the wear track for A17075 alloy and the hybrid composites are listed in Table 2. Both the wear-track depth and width, which are criteria of the volume of worn material, were reduced due to adding $\mathrm{SiC}$ and increase of the amount of graphene to $0.5 w / \%$. The reason for the improved wear resistance of the composite samples is their hardness (Figure 2), which is the result of the presence of $\mathrm{SiC}$ nanoparticles and graphene. In this way, the reinforcing phases act as load-bearing elements and reduce the actual contact area between the counterface and $\mathrm{Al}$ matrix. This improves the wear resistance.

In order to investigate the wear mechanism, the surfaces of the worn samples were examined under the SEM. Figure 3 shows the SEM morphology of the worn surfaces for three composites under dry-sliding conditions. In Figure 3a and Figure 3b it can be found that there are very obvious abrasive grooves in the sliding direction. This indicates that the wear process mainly took place by abrasive wear for the Al-SiC composite. This is consistent with the wear mechanism of Al-SiC

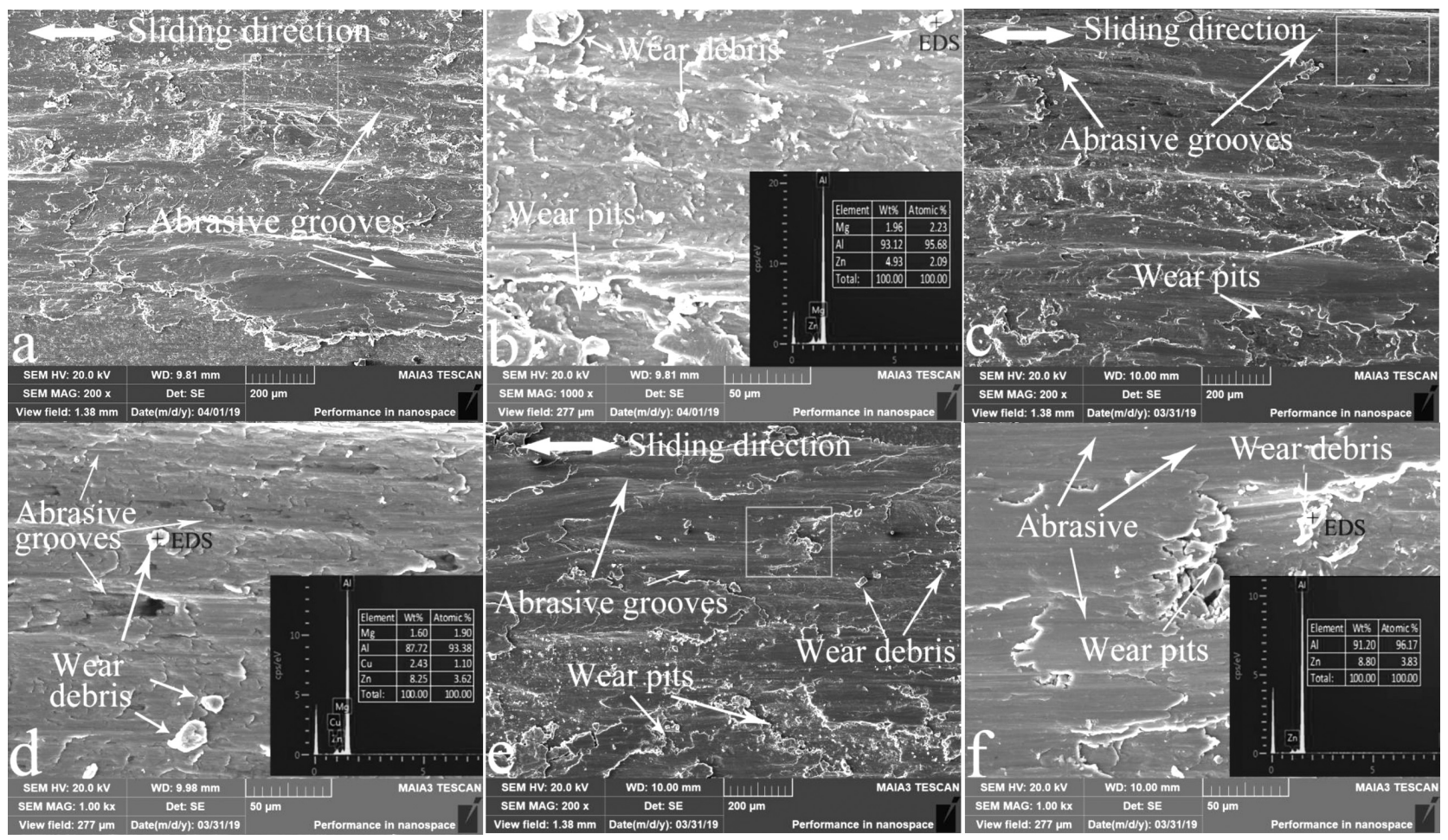

Figure 3: SEM micrographs of the worn surface of: a) Al-SiC, c) Al-SiC-Gr1, e) Al-SiC-Gr2 and b) Al-SiC, d) Al-SiC-Gr1, f) Al-SiC-Gr2 is a magnified picture corresponding to the local area of the worn surface, inset of: b), d) and f) are the EDS results of the wear debris 
composites reported by J. Zhang et al. ${ }^{23}$ The deep abrasive grooves observed in Figure 3a most probably produced by pushing the $\mathrm{SiC}$ nanoparticles on the surface of the $\mathrm{Al}$ matrix. This process is equivalent to micro-cutting of aluminum matrix surface with $\mathrm{SiC}$ particles. A three-body wear state is formed between the worn sample surface and the friction pair. ${ }^{5}$ In addition, the surface patch state and wear pits $^{11}$ caused by adhesive wear can be observed on the worn surface. It is also found that there are many wear debris adhered to the worn surface. EDS results show that these wear debris mainly originate from the aluminum matrix.

In Figure 3c and Figure 3d there are still some abrasive grooves. However, those abrasive grooves are shallow and which of surfaces are nearly covered by adhesive layers. It is indicated that the wear mechanism of Al-SiC-Gr1 composite is the combination of abrasive wear and delamination wear. In Figure 3e and Figure $3 f$ the abrasive grooves on the worn surface of the Al-SiC-Gr2 composite almost disappear. On the worn surfaces, areas with a fractured appearance can be observed. It can be seen that the layer of material has been removed as debris from the surface and that the debris is in the form of thin sheets. In reference to SEM studies of worn surfaces, it could be observed that wear damage was caused by the plastic flow of the matrix, indicating that the delamination wear is the dominant wear mechanism of the Al-SiC-Gr2 composite. It is concluded that the wear mechanism of Al-SiC-graphene composites transfers from abrasive wear to the delamination wear with the increase of graphene content in composites.

Figure 4 shows SEM micrographs of the worn surfaces of the balls corresponding to the three composite samples.

The large number of abrasive grooves can be found in Figure 4a. This confirms that the three-body abrasive wear exists in the dry-sliding wear test for Al-SiC composite. For Al-SiC-Gr1 composite, there are only a few abrasive grooves and adhesive layers on the worn surfaces of the ball (Figure 4b). However, there are only few abrasive grooves and a lot of adhesive layers on the worn surfaces of the ball for Al-SiC-Gr2 composite, as shown in Figure 4c. Moreover, a large amount of wear debris is also coated on the surface of the balls. Al adhesion can be found on the surface of the ball from the EDS result (Figure 4d). These results are consistent with the wear-surface analysis results of the composites mentioned above.

Studying the shapes and sizes of the wear debris provides clues to the wear mechanisms extant and brings information about the wear state. Figure 5 shows SEM micrographs of the wear debris of three composite samples. There are three types of wear debris according to their morphology and sizes:

1) flake wear debris. This wear debris is the most common form, with sizes ranging from $100 \mu \mathrm{m}$ to 300 $\mu \mathrm{m}$. Flakes can be observed in Figure $\mathbf{5} \mathbf{a}$ and Figure 5b, ranging in thickness from $10 \mu \mathrm{m}$ to $30 \mu \mathrm{m}$. This debris is caused by adhesion in the sliding direction and delamination of the balls.
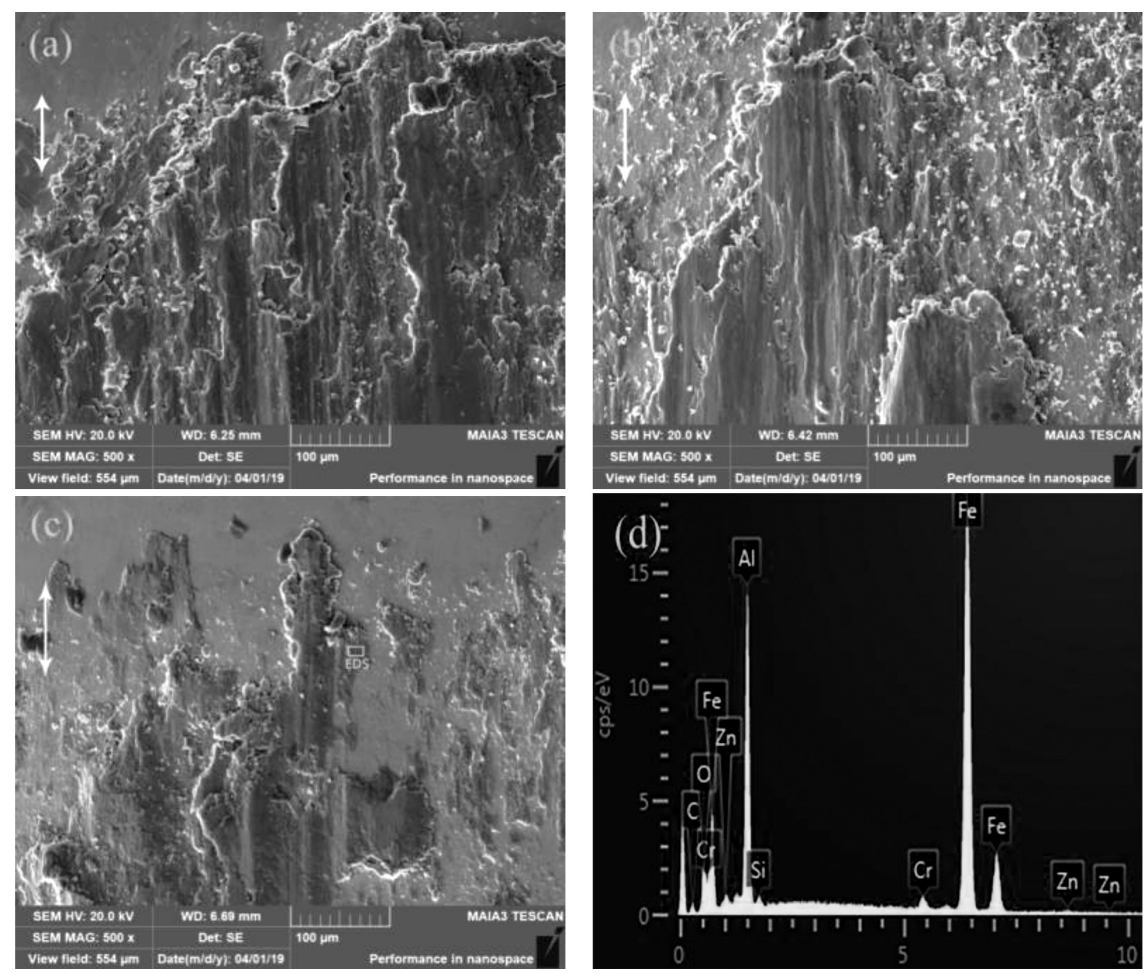

Figure 4: SEM micrographs of the surfaces of balls used by: a) Al-SiC, b) Al-SiC-Gr1, c) Al-SiC-Gr2, d) the EDS of the selected area in c) 


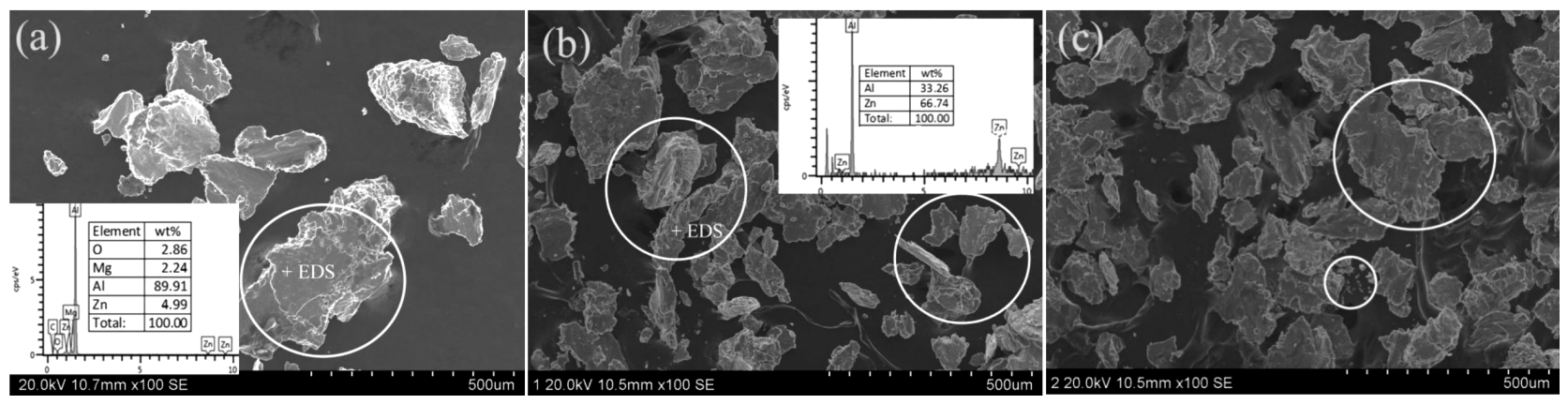

Figure 5: SEM micrographs of wear debris of: a) Al-SiC, b) Al-SiC-Gr1, c) Al-SiC-Gr2, inset of: a) and b) are the EDS results of the wear debris

2) fine debris. Contrary to large wear debris, a small number of fine particles as well as sheet-like wear debris with an range of $1 \mu \mathrm{m}$ to $20 \mu \mathrm{m}$ in planar are also collected (Figure 5b and Figure 5c). The generation of fine wear debris is attributed to an abrasive micro-cutting effect. Generally, the appearance of a smaller size of wear debris is related to better anti-wear performance of the material. 3) corrugated debris. The amount of the debris is very small. It can be observed that there are many obvious layers on the surface of the debris. It is mainly due to the joint action of shear force and constant friction force in the sliding direction. ${ }^{23-24}$ The results of EDS analysis indicate that most of the wear particles origin from aluminum alloy matrix.

In order to investigate the evolution of graphene in the process of hot-pressing and sliding, Raman spectroscopy analysis was performed on graphene, as-prepared $\mathrm{Al}-\mathrm{SiC}-\mathrm{Gr} 2$ composite and the wear track of Al-SiC-Gr2 composite, respectively, as shown in Figure 6. It is clear from Figure 6 that the typical D-band (from defect), G-band (from graphite), and 2D band (shape of the second-order Raman bands) of graphitic carbons are detected at $1335 \mathrm{~cm}^{-1}, 1590 \mathrm{~cm}^{-1}$, and $2773 \mathrm{~cm}^{-1}$ respectively, for the initial material. ${ }^{25-27}$ During hot pressing, the band shift and broadening can occur by structural defects and domain size in graphitic materials,

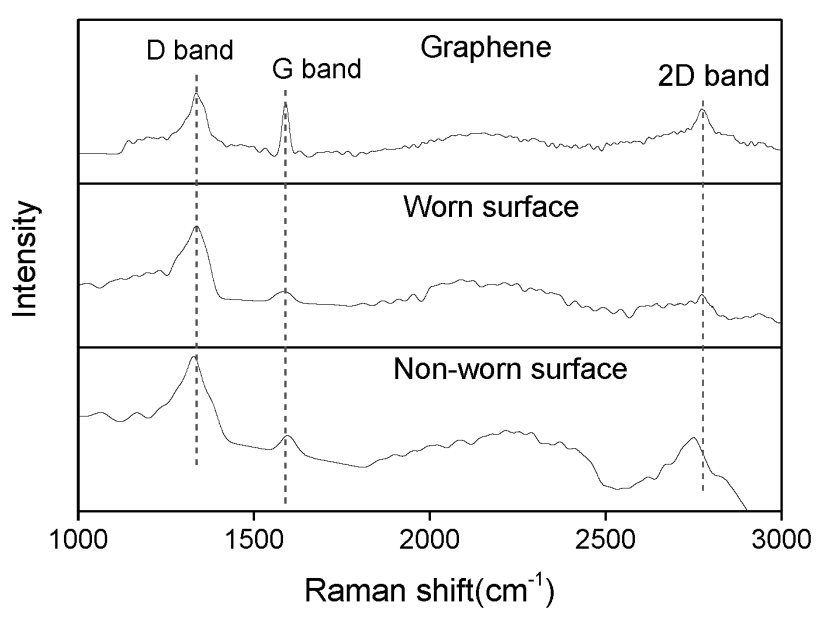

Figure 6: Obtained Raman spectra on: a) graphene, b) worn surface of Al-SiC-Gr2, c) non-worn surface of Al-SiC-Gr2 and damage of crystalline graphitic structure. However, the band broadening can only be observed during sliding.

This shift and broadening can be attributed to the residual strain in the graphitic materials, ${ }^{28-29}$ which is induced by the compressive stress during hot-pressing and the shear stress at the contact surface during sliding, resulting in the structure disruption of the graphene.

The ratio of the intensity of the $D$ band to the intensity of the $G$ band $\left(I_{\mathrm{D}} / I_{\mathrm{G}}\right)$ is normally used to characterize the degree of defects of the graphite-based material. ${ }^{30}$ The larger $I_{\mathrm{D}} / I_{\mathrm{G}}$ ratio represents the higher defect density in the graphitic structure. The results show that the $I_{\mathrm{D}} / I_{\mathrm{G}}$ $=1.30$ of worn surface is higher than that of the initial graphene $\left(I_{\mathrm{D}} / I_{\mathrm{G}}=1.01\right)$ and non-worn surface $\left(I_{\mathrm{D}} / I_{\mathrm{G}}=\right.$ 1.25). This indicates more exfoliated and fragmented graphene flakes contribute to the formation of a lubricating tribolayer on the contact interface, resulting in an improved wear resistance. A similar result has been observed by other authors for copper-matrix composites containing graphene. ${ }^{31}$

\section{CONCLUSIONS}

In the present work, graphene and $\mathrm{SiC}$ nanoparticles hybrid reinforced A17075 composites were prepared by hot pressing. The microstructure, hardness and wear behavior were studied. X-ray diffraction analysis showed the presence of the carbon peaks and no proof of $\mathrm{Al}_{4} \mathrm{C}_{3}$ formation. The graphene content in the base Al 7075 gives rise to a significant improvement in the hardness, density and wear resistance. The extensive increase in hardness of the $\mathrm{Al} 7075$ matrix composites is due to the dispersion strengthening of the $\mathrm{SiC}$ nanoparticles and graphene, refining grain strengthening of $\alpha$-Al matrix and thermal mismatches between $\alpha$-Al and $\mathrm{SiC}$, graphene. Consistent with the hardness improvements, were marked improvements in wear resistance. On increasing the graphene content, the coefficient of friction values were reduced and were consistent with the theoretically calculated friction coefficient of composite materials. The coefficient of friction decreased by about $22 \%$ and $43 \%$ with the reinforcement of $0.25 w / \%$ and $0.5 w / \%$ graphene, respectively. SEM observation along with EDS for the worn surfaces, counter-face and debris shows that the wear mechanism 
of $\mathrm{Al}$-SiC-graphene composites transfers from abrasive wear to delamination wear with the increase of graphene content in composites and confirms the formation of graphene lubricating tribolayer between the wear surfaces, which influences the effect of wear behaviour and coefficient of friction values in the composites. The Raman spectroscopy confirms the increase of $I_{\mathrm{D}} / I_{\mathrm{G}}$ ratio of the graphene after hot pressing, indicating the graphene is to some extent disrupted in the structure during the hot-pressing process. The $I_{\mathrm{D}} / I_{\mathrm{G}}$ ratio reaches a maximum after sliding, which demonstrates the formation of a graphene-rich lubricating tribolayer at the contact surface, which hinders the friction and wear.

\section{Acknowledgment}

This work was supported by Shenyang Science and Technology Project (No.18-013-0-33), Shenyang Young and Middle-aged Science and Technology Innovation Talents Project (RC180214) in Liaoning Province, China.

\section{REFERENCES}

${ }^{1}$ M. O. Bodunrin, K. K. Alaneme, L. H. Chown, Aluminium matrix hybrid composites: a review of reinforcement philosophies; mechanical, corrosion and tribological characteristics, J. Mater Res. Technol., 4 (2015) 4, 434-445, doi:10.1016/j.jmrt.2015.05.003

${ }^{2}$ S. F. Bartolucci, J. Paras, M. A. Rafiee, J. Rafiee, S. Lee, D. Kapoor, N. Koratkar, Graphene-aluminum nanocomposites, Mater. Sci. Eng. A, 528 (2011) 27, 7933-7937, doi:10.1016/j.msea.2011.07.043

${ }^{3}$ F. H. Latief, El-Sayed M. Sherif, Effects of sintering temperature and graphite addition on the mechanical properties of aluminum, J. Ind. Eng. Chem., 18 (2012) 6, 2129-2134, doi:10.1016/j.jiec.2012.06.007 ${ }^{4}$ L. Jiang, G. Fan, Z. Li, X. Kai, D. Zhang, Z. Chen, S. Humphries, G. Heness, W. Y. Yeung, An approach to the uniform dispersion of a high volume fraction of carbon nanotubes in aluminum powder, Carbon, 49 (2011) 6, 1965-1971, doi:10.1016/j.carbon.2011.01.021

${ }^{5}$ V. K. Varma, S. V. Kamat, Y. R. Mahajan, V. V. Kutumbarao, Effect of reinforcement size on low strain yielding behaviour in $\mathrm{Al}-\mathrm{Cu}-\mathrm{Mg} / \mathrm{SiCP}$ composites, Mater. Sci. Eng. A, 318 (2001) 1-2, 57-64, doi:10.1016/s0921-5093(01)01337-5

${ }^{6}$ E. M. Sharifi, F. Karimzadeh, M. H. Enayati, Fabrication and evaluation of mechanical and tribological properties of boron carbide reinforced aluminum matrix nanocomposites, Mater. Design, 32 (2011) 6, 3263-3271, doi:10.1016/j.matdes.2011.02.033

${ }^{7}$ J. M. Zhan, W. R. Jian, X. C. Tang, Y. L. Han, W. H. Li, X. H. Yao, L. Y. Meng, Tensile deformation of nanocrystalline Al-matrix composites: Effects of the SiC particle and graphene, Comp. Mater. Sci., 159 (2019), 187-194, doi:10.1016/j.commatsci.2018.09.050

${ }^{8}$ X. M. Du, K. F. Zheng, F. G. Liu, Effect of clustering on the mechanical properties of $\mathrm{SiC}$ particle reinforced aluminum metal matrix composites, Dig. J. Nanomater. Bios, 13 (2018) 1, 253-261

${ }^{9}$ M. R. Akbarpour, M. Najaf, S. Alipour, H. S. Kim, Hardness, wear and friction characteristics of nanostructured $\mathrm{Cu}-\mathrm{SiC}$ nanocomposites fabricated by powder metallurgy route, Mater. Today. Commun., 18 (2019), 25-31, doi:10.1016/j.mtcomm.2018.11.001

${ }^{10}$ F. Akhlaghi, A. Lajevardi, H. M. Maghanaki, Effects of casting temperature on the microstructure and wear resistance of compocast A356/SiCp composites: a comparison between SS and SL routes, J. Mater. Process. Technol., 155-156 (2004), 1874-1880, doi:10.1016/j.jmatprotec.2004.04.328
${ }^{11}$ W. Ames, A. T. Alpas, Wear mechanisms in hybrid composites of Graphite-20 Pct SiC in A356 Aluminum Alloy (Al-7 Pct Si-0.3 Pct Mg), Metall. Mater. Trans. A, 26 (1995) 1, 85-98, doi:10.1007/ bf02669796

${ }^{12}$ D. Berman, A. Erdemir, A. V. Sumant, Graphene: a new emerging lubricant, Mater. Today, 17 (2014) 1, 31-42, doi:10.1016/j.mattod. 2013.12.003

${ }^{13}$ D. Berman, A. Erdemir, A. V. Sumant, Reduced wear and friction enabled by graphene layers on sliding steel surfaces in dry nitrogen, Carbon, 59 (2013), 167-175, doi:10.1016/j.carbon.2013.03.006

${ }^{14}$ M. R. Akbarpour, S. Alipour, A. Safarzadeh, H.S. Kim, Wear and friction behavior of self-lubricating hybrid $\mathrm{Cu}-(\mathrm{SiC}+\mathrm{x} \mathrm{CNT})$ composites, Compos. Part B, 158 (2019), 92-101, doi:10.1016/ j.compositesb.2018.09.039

${ }^{15}$ A. Vencl, F. Vučetić, B. Bobić, J. Pitel, I. Bobić, Tribological characterisation in dry sliding conditions of compocasted hybrid A356/SiCp/Grp composites with graphite macroparticles, Int. J. Adv. Manuf. Technol., 100 (2018) 9-12, 2135-2146, doi:10.1007/ s00170-018-2866-0

${ }^{16}$ X. M. Du, K. F. Zheng, T. Zhao, F. G. Liui, Fabrication and characterization of al 7075 hybrid composite reinforced with graphene and sic nanoparticles by powder metallurgy, Dig. J. Nanomater. Bios, 13 (2018) 4, 1133-1140

${ }^{17}$ G. K. Williamson, W. H. Hall, X-ray line broadening from filed aluminium and wolfram, Acta Metallurgica, 1 (1953) 1, 22-31, doi:10.1016/0001-6160(53)90006-6

${ }^{18}$ P. Garg, P. Gupta, D. Kumar, O. Parkash, structural and mechanical properties of graphene reinforced aluminum matrix composites, J. Mater. Environ. Sci., 7 (2016) 5, 1461-1473

${ }^{19}$ P. V. Trinh, T. B. Trung, N. B. Thang, B. H. Thang, T. X. Tinh, L. D. Quang, D. D. Phuong, P. N. Minh, Calculation of the friction coefficient of $\mathrm{Cu}$ matrix composite reinforced by carbon nanotubes, Comp. Mater. Sci., 49 (2010) 4, S239-S241, doi:10.1016/ j.commatsci.2010.01.035

${ }^{20}$ C. Lee, X. Wei, J. W. Kysar, J. Hone, Measurement of the elastic properties and intrinsic strength of monolayer graphene, Science, 321 (2008), 385-388, doi:10.1126/science.1157996

${ }^{21}$ D. Berman, S. A. Deshmukh, S. K. R. S. Sankaranarayanan, A. Erdemir, A. V. Sumant, Macroscale superlubricity enabled by graphene nanoscroll formation, Science, 348 (2015), 1118-1122, doi:10.1126/science. 1262024

${ }^{22}$ Z. Yuan, Y. He, K. Cheng, Z. Duan, L. Wang, Effect of self-developed graphene lubricant on tribological behaviour of silicon carbide/silicon nitride interface, Ceram. Int., 45 (2019) 8 , 10211-10222, doi:10.1016/j.ceramint.2019.02.073

${ }^{23}$ J. Zhang, S. Yang, Z. Chen, H. Wua, J. Zhao, Z. Jiang, Graphene encapsulated $\mathrm{SiC}$ nanoparticles as tribology-favoured nanofillers in aluminium composite, Compos. Part B, 162 (2019), 445-453, doi:10.1016/j.compositesb.2018.12.046

${ }^{24}$ S. Kumar, R. S. Panwar, O. P. Pandey, Effect of dual reinforced ceramic particles on high temperature tribological properties of aluminum composites, Ceram. Int., 39 (2013) 6, 6333-6342, doi:10.1016/j.ceramint.2013.01.059

${ }^{25}$ S. E. Shin, H. J. Choi, J. H. Shin, D. H. Bae, Strengthening behavior of few-layered graphene/aluminum composites, Carbon, 82 (2015), 143-151, doi:10.1016/j.carbon.2014.10.044

${ }^{26}$ S. E. Shin, Y. J. Ko, D. H. Bae, Mechanical and thermal properties of nanocarbon-reinforced aluminum matrix composites at elevated temperatures, Compos. Part B, 106 (2016), 66-73, doi:10.1016/ j.compositesb.2016.09.017

${ }^{27}$ K. N. Kudin, B. Ozbas, H. C. Schniepp, R. K. Prud'homme, I. A. Aksay, R. Car, Raman spectra of graphite oxide and functionalized graphene sheets, Nano. Lett., 8 (2008) 1, 36-41, doi:10.1021/ nl071822y

${ }^{28}$ G. Tsoukleri, J. Parthenios, K. Papagelis, R. Jalil, A. C. Ferrari, A. K. Geim, K. S. Novoselov, C. Galiotis, Subjecting a graphene mono- 


\section{K. ZHENG et al.: SLIDING-WEAR BEHAVIOR OF ALUMINUM-MATRIX COMPOSITES ...}

layer to tension and compression, Small., 5 (2009) 21, 2397-2402, doi:10.1002/smll.200900802

${ }^{29}$ J. Liao, M. J. Tan, Mixing of carbon nanotubes (CNTs) and aluminum powder for powder metallurgy use, Powder Technol., 208 (2011) 1, 42-48, doi:10.1016/j.powtec.2010.12.001

${ }^{30}$ S. N. Alam, L. Kumar, mechanical properties of aluminium based metal matrix composites reinforced with graphite nanoplatelets, Mater. Sci. Eng. A, 667 (2016), 16-32, doi:10.1016/j.msea.2016. 04.054

${ }^{31}$ J. F. Li, L. Zhang, J. K. Xiao, K. C Zhou, Sliding wear behavior of copper-based composites reinforced with graphene nanosheets and graphite, Trans. Nonferrous Met. Soc. China, 25 (2015) 10, 3354-3362, doi:10.1016/S1003-6326(15)63970-X 